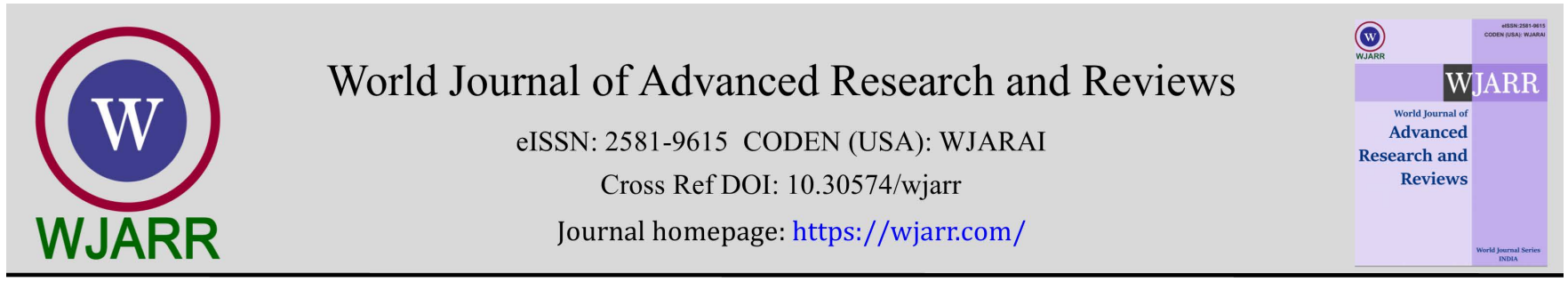

(REVIEW ARTICLE)

Check for updates

\title{
Economic analysis of halal certification by the Halal Product Assurance Administration Agency
}

\author{
Mohammad Yusuf, Dewi Mahrani Rangkuty *, Robi Krisna and Mochammad Erwin Raditio \\ Universitas Pembangunan Panca Budi, Medan, North Sumatera, Indonesia.
}

World Journal of Advanced Research and Reviews, 2022, 13(01), 556-564

Publication history: Received on 18 December 2021; revised on 19 January 2022; accepted on 21 January 2022

Article DOI: https://doi.org/10.30574/wjarr.2022.13.1.0077

\begin{abstract}
This study analyzes the economics of halal certification by the Halal Product Assurance Administration Agency (HPAAA). This research aims to make it easier for MSEs to manage the business certification process for their business. The ease of obtaining halal certification for business actors provides economic benefits.

The economic side of the analysis is to provide convenience and simplification of submitting applications for halal certification so that business actors and economic actors will provide comfort in marketing their products that have been certified halal. Another advantage of halal certification is that the product is known in the national market. Product sales are increasing with a halal certification logo and guaranteeing halal certainty on products that business actors have produced.

The method in this research is qualitative. This research is sharpened through data analysis by categorizing various data and arguments to explain the policy model for halal product assurance certification. The data obtained will also be mapped based on the sequence of time, events, subject, and place determination. The point is to chronologically describe what happened in the political economy of halal certification. The next step that needs to be done is to understand the background of the emergence of the halal certification policy to digest the various problems that exist in it and further understand whether or not there is a tendency for certain political motives and interests. The last step is to construct the existing policy model precisely by describing it appropriately.

The conclusion in this study is that halal certification seen from economic factors will increase the profits of business actors because people from various economic strata, if they want to buy food, drinks, and the like, are required to see the halal certification logo with the aim that the food and beverages consumed are guaranteed halal. Meanwhile, from an economic perspective, the goods or services offered by producers to the public will be profitable if business actors have halal certification compared to business actors who do not have halal certification, and have an impact on increasing sales of halal products, so with this impact. These business actors do not have halal certification. The halal certificate will take care of the halal certificate to the local HPAAA.
\end{abstract}

Keywords: Economic Analysis; Halal Certification; Halal Product; HPAAA; Muslim

\section{Introduction}

Muslim communities worldwide have formed a potential market segment due to their particular pattern of consuming a product. This pattern of consumption is regulated in Islamic teachings called Sharia. In the teachings of Sharia, it is not permissible for Muslims to eradicate certain products because the substance they contain or the accompanying process is not under the teachings of the Shariah.

\footnotetext{
* Corresponding author: Dewi Mahrani Rangkuty

Universitas Pembangunan Panca Budi, Medan, North Sumatera, Indonesia.
}

Copyright ( $(2022$ Author(s) retain the copyright of this article. This article is published under the terms of the Creative Commons Attribution Liscense 4.0. 
With this strict rule, marketers have the opportunity to target a unique market for Muslims. The strict teachings of Islamic Sharia are to avoid things prohibited by Allah SWT and do whatever is ordered to make Muslim consumers not permissive consumers in their consumption patterns. They are limited by the idolatry and prohibition contained in the Qur'an and The Hadith, which is the leading guide for them.

The application of halal industry is a trend for countries worldwide to accelerate the country's economic growth in the face of the decline of the traditional economy. Some non-Muslim countries are also developing the halal industry in their countries, and an example is Japan. Japan is developing facilities for Muslim tourists for both domestic and foreign tourists, such as places of worship, halal certification for food consumption, and lodging. This is also due to Japan's desire to reach 20 million foreign tourists who visit Japan by 2020.

Another non-Muslim country is Canada. The country implements the halal industry through the development of halal certificates. Namely, there are already more than 500 restaurants throughout Canada that are halal certified. This halal certificate is issued by HMA (Halal Monitoring Authority) as Canada's trusted halal certification body. In addition to certification, the Government of Canada and HMA organize several halal events in Canada, such as MuslimFest, and Halal Food Festival.

In addition to 2 countries, namely Japan and Canada, China is also developing the halal industry in its country. The halal industry development in China cannot be separated from the role of Muslims in China, who are also producers of halal products. Muslims in China are developing the halal industry in Ningxia province, more precisely in Wuchang. The development also includes the establishment of 10,000 factories in halal industrial estates across China and many good restaurants selling halal-certified food and beverage products in China.

Another non-Muslim majority country was developing the halal industry in South Korea, a development caused by the increase in Muslims in South Korea and the increase in Muslim foreign tourists visiting the country. The number of foreign or domestic tourists is also offset by the development of South Korea's domestic halal industry with the organization, namely the Korea Muslim Federation Halal Committee and the Korea Halal Association. The existence of this organization, South Korea's halal sector, is also growing because it makes it easier for companies to get halal certification in food and beverage products, get promotions, and participate in activities such as festivals, conferences either local or international level.

From Southeast Asian countries, Singapore is developing its halal industry. The halal industry in Singapore has even begun to grow since 1978 with the halal logo on food products issued by the Islamic Ulema Council of Singapore. In addition, halal certification issued by the Islamic Ulema Council of Singapore is a halal certification that is entirely recognized and used by several Multi-National Corporations worldwide, such as McDonald's, KFC, and Taco Bell. In addition to being recognized by several Multi-National Corporations, Singapore's halal product certification is also recognized by several countries in Southeast Asia such as Indonesia, Brunei Darussalam, Malaysia, and governments from the Gulf Cooperations Council organization.

But in fact, secular countries or non-Islamic countries have included halal labels on their products in recent years. Call it Australia1, New Zealand, Singapore, Thailand2, France, Japan, Canada, the United States, and several other countries. Of course, Islamic countries such as Saudi Arabia and the Middle East, Malaysia, and Brunei Darussalam have long been protected through halal certification.

The number of Muslim consumers reached 204.8 million people in Indonesia, making the Indonesian market a huge Muslim consumer market. Therefore, the guarantee of halal products becomes an important thing to get the attention of the State. As stated in the Opening of the Constitution of the Republic of Indonesia in 1945, the State is obliged to protect the entire Indonesian nation and all Indonesian blood and realize the general welfare. In today's food industry, food is processed through various new techniques and methods of processing, utilizing the development of science and technology to become a product that is ready to be marketed for consumption by people around the world. However, in reality, most food products and technology for food processing in the world do not implement a halal certification system. This raises concerns if food products are circulating in Indonesia containing or contaminated with illegal materials in terms of processing, storage, handling, and packing techniques using preservatives that endanger health or additives containing haram elements that are clearly prohibited in Islam.

Related to certification and proof of the idolatry of a food commodity has attracted considerable attention to protecting Indonesian Muslim consumers. The creation of Law No. 33 of 2014 on Halal Product Guarantee aims to ensure that consumers get legal certainty on food products and other consumer goods. As for business people, the presence of guides on how to process, process, produce, and market products to the consumer community and make halal product 
information to consumers. UUJPH is intended to provide protection and guarantees to consumers only by providing halal certification. Manufacturers also reap the benefits of this law with legal certainty on all goods produced so that UUJPH will positively impact the business world. Halal product guarantee for each product can also benefit companies, considering that halal-certified products will be preferred and favored by consumers to increase sales. This is not only in demand by Muslims and non-Muslim communities because non-Muslim communities assume that halal products are proven to be of quality and very good for the health of the human body.

Halal can be defined as a quality standard that complies with Islamic Sharia law and is used in every activity carried out by Muslims. Muslims choose halal products and services to adhere to Islamic Sharia law. Although halal is closely related to Muslims, it does not mean that halal products only come from Muslims. Consumers of halal products originating from countries with minority Muslim populations have increased significantly in recent years. The quality of halal products, commonly known as Halalan Thoyyiban, is why non-Muslims use halal products because there are guarantees of cleanliness, safety, and product quality for the entire production chain (from farm to plate). With the largest Muslim population in the world, Indonesia has excellent market potential for the world halal industry, one of which is for the halal food industry and is listed as the largest consumer of halal products globally. According to 2015/2016 State of the Global Islamic Economy Report (published by Thomson Reuters in collaboration with Dinar Standard), Indonesian spending on halal food reached $\$ 157$ billion in 2014, outperforming Turkey (U\$109 billion) and Pakistan (U $\$ 100$ billion).

Why then did halal certification widen into a trading commodity? First, halal certification can no longer be a mere "form of trust." In other words, halal certification is nothing but an effort to anticipate the forms of fraud over the halal content in a product. For example, in processed meat products partly considered halal by the Muslim community. But when further investigated, the processed meat contained ingredients or processes that are not halal. So, in this case, the state acts as a supervisor by making certification a means required to entrepreneurs. The state implements a general order (law and order) to achieve common goals and prevent clashes in society. That said, the state acts as a stabilizer. The role of this stabilizer is carried out through halal certification instruments that are applied to the business world. Second, seeing the implementation of halal certification in non-Islamic countries indeed invites questions. What is the function of halal certification in non-Islamic countries if Muslims in that country are just a minority group? The answer can be seen from many perspectives. But we know, those non-Islamic countries are mainly developed countries located in continental Europe, North America, and East Asia.

Products and industrial products are more widely marketed in developing countries, most of which are Islamic countries. 3 If it is later known that the products offered contain illegal substances, they will undoubtedly be rejected outright by Muslims. The inclusion of halal certification on products from developed countries can be said to be an effort of the trading strategy. This is also done as a defense effort or to increase the number of consumers in countries used as marketing. Third, there is a motive to benefit from the marketing of halal products. According to the estimates of Sdn Bhd's Director of Global Food Research and Advisory, Irfan Sungkar, in Kuala Lumpur, as reported on the halalguide.info website in 2007, the world's halal industry reached a value of more than 600 billion US dollars with a Muslim population of about 1.6 billion people (Firmansyah, 2010, http://sacafirmansyah wordpress.com. What about Indonesia? Indonesia is a very potential market for the production and distribution of halal goods. This is inseparable from the most significant number of Muslims in the world. A survey conducted by the Institute for the Assessment of Food, Medicine, and Cosmetics of the Indonesian Ulema Council (LP POM MUI) in 2010 showed that public concern for halal products increased. In 2009 it was 70 percent and increased to 92.2 percent in 2010. Thus, halal certification in Indonesia appears as an obligation that must be fulfilled and as a symbol to meet the interests of the majority of Muslims.

The presence of halal certification is received with open arms by the community. Every product that enters, circulates and is traded in the territory of Indonesia must be certified halal. That means every domestic and foreign product sold in Indonesia must have a halal certificate to provide legal certainty to Muslim consumers through the certification process.

This halal product guarantee itself is organized by a body, namely the Halal Product Assurance Agency which is responsible for and domiciled under the minister of religion. In addition, to facilitate the implementation of JPH in the area, a Halal Certification Service Task Force was established in accordance with the Decree of the Minister of Religious Affairs Number B.II/3/33453 of 2019 concerning the Determination of Regional Halal Certification Service Coordinators.

Halal certificate obligations for products circulating and traded in the territory of Indonesia came into force 5 (five) years from the date the UUJPH was enacted on October 17, 2014. This is confirmed by issuing Government Regulation of the Republic of Indonesia Number 31 of 2019 on Regulation of Implementation of Law No. 33 of 2014 on Halal Product 
Guarantee. Therefore, beginning in October 17, 2019, all products circulating in the territory of Indonesia must have a halal certificate, not least for fast food produced by micro-businesses.

The Ministry of Religious Affairs has the task of conducting halal product guarantees following Law No. 33 of 2014 on Halal Product Guarantee and Government Regulation No. 31 of 2019 on The Implementation of Law No. 33 of 2014 halal product guarantee. Referring to the Law and the PP, HPAAA carries out the implementation of halal product guarantees. HPAAA is authorized to issue halal certificates on products that enter, circulate, and are traded in the territory of Indonesia.

In exercising its authority, HPAAA cooperates with relevant ministries and institutions, Indonesian Council of Religious Scholars, and Halal Examiner, to achieve the goal of implementing halal product guarantees, namely providing comfort, security, safety, and certainty of the availability of halal products for the public in consuming and using products, and increasing added value for business actors to produce and sell halal products.

The halal industry in Indonesia is currently proliferating with various products, especially food and beverage products, in accordance with the diversity of Indonesian culture that is rich in flavor. This is influenced by public awareness of the need for halal certificates on products and becomes an opportunity for businesses to develop and distribute their products in the territory of Indonesia. In the economy's structure, the scale of micro and small businesses is the most significant layer of business actors and has tremendous leverage in the halal value chain. The micro and small business sector directly strengthens the halal industry and therefore needs to get attention and support in halal certification.

To support the ease of access of business actors in obtaining halal certification services, HPAAA develops the governance of halal certification services for business actors, especially micro and small businesses. In this regard, HPAAA streamlines facilities and infrastructure in the Ministry of Religious Affairs so that halal certification services are carried out in the area effectively and efficiently. Effective and efficient implementation of halal certification services needs to be followed by changes in work culture so that halal certification service standards are required.

\section{Literature Review}

\subsection{Halal Product Assurance Administration Agency (HPAAA)}

Law No. 33 of 2014 Halal Product Guarantee. Referring to the Law and the PP, BPJPH carries out the implementation of halal product guarantees. BPJPH is authorized to issue halal certificates on products that enter, circulate, and are traded in the territory of Indonesia. In exercising its authority, BPJPH cooperates with relevant ministries and institutions, MUI, and LPH, to achieve the goal of implementing halal product guarantees, namely providing comfort, security, safety, and certainty of the availability of halal products for the public in consuming and using products, and increasing added value for business actors to produce and sell halal products.

The halal industry in Indonesia is currently overgrowing with various products, especially food and beverage products, in accordance with the diversity of Indonesian culture that is rich in flavor. This is influenced by public awareness of the need for halal certificates on products and becomes an opportunity for businesses to develop and distribute their products in the territory of Indonesia.

In the economy's structure, the scale of micro and small businesses is the most significant layer of business actors and has excellent leverage in the halal value chain. The micro and small business sector directly strengthens the halal industry and therefore needs to get attention and support in halal certification. To support the ease of access of business actors in obtaining halal certification services, HPAAA develops the governance of halal certification services for business actors, especially micro and small businesses. In this regard, HPAAA streamlines facilities and infrastructure in the Regional Office of the Ministry of Religious Affairs so that halal certification services are carried out in the area effectively and efficiently. The implementation of effective and efficient halal certification services needs to be followed by changes in work culture so that the purpose of the implementation procedure of HPAAA Halal Certification Service and Regional Halal Certification Service Task Force is:

- Improving the quality of halal certification services, which is the main task of the Halal Product Assurance Agency.

- Guide service implementers both at BPJPH Pusat (from now on called HPAAA) and Regional Halal Certification Service Task Force (referred to as Regional Task Force) with customer satisfaction oriented, providing access and speed of service. 
The goal to be achieved with this Implementation Procedure is so that the services carried out by BPJPH and the Regional Task Force are following procedures, procedures, compliance with regulations, and service management, to provide the best service to the community.

Halal certificate application submitted by Business Actors through HPAAA and Regional Task Force (via PTSP) must be equipped with documents:

- Halal Certificate Application Letter, addressed to the Head of Halal Product Assurance Agency (Head of HPAAA). Example of Application Letter as form 1.

- Halal Certification Registration Form (can be downloaded through the website), by attaching documents:

\subsubsection{Legal aspects of the company}

- A Copy of the Attempted Parent Number.

- If you do not have the Attempted Parent Number, it can be replaced with SIUP/IUMK/IUI/API/others. For Micro, Business Actors can be replaced with NPWP and Identity Number.

\subsubsection{Halal Supervisory Document}

- Copy of ID card.

- A copy of the decree establishing halal supervisors.

- Curriculum vitae.

- A copy of the halal supervisor's certificate (if any).

\subsubsection{A copy of the license/certificate of healthy.}

- list of product names and ingredients/menus/items.

- Product Processing Contains information on purchase, receipt, storage of materials used, processing, packaging, finished products, and distribution.

- Halal Product Assurance System (SJPH)

- Halal Product Assurance System (SJPH) is a management system document compiled, implemented, and maintained by business actors to maintain the continuity of halal production processes. BPJPH will establish this Halal Product Assurance System.

- About the fulfillment of the current requirements, the SJPH document used is the halal assurance system that applies in the current Halal Examiner.

- Power of Attorney For direct applications other than the person in charge of the company.

- Copies of halal certificates issued by MUI for products that have been halal certified.

Halal certification system, mechanism, and procedure consist of the following stages:

- Application for Halal Certificate

- Document Completeness Check

- Determination of LPH to conduct inspection/testing of the product page

- Inspection and Testing of Products

- Submission of Product Inspection and Testing Results from LPH to BPJPH

- Submission of Inspection Results and Product Reliability Testing from BPJPH to MUI

- Determination of Product Page by MUI

- Submission of Product Page Determination Results from MUI to BPJPH

- Issuance of Halal Certificate Based on The Results of Product Reliability Determination from MUI by BPJPH

- Delivery of Halal Certificate from BPJPH to Business Actors.

\section{Halal Certification}

Halal Certificate is a written fatwa from the Indonesian Ulema Council (MUI) that states the idolatry of a product following the Islamic Shari'ah. This Halal Certificate is a condition to obtain a permit to include halal labels on product packaging from authorized government agencies.

A Halal Certificate guarantees security for a Muslim consumer to choose good food for him and follow religious rules. Food products that have halal certificates are products that, in the processing process, meet standards in safety and cleanliness. Every company or business engaged in food and beverage will not be separated from halal certificates. 
Namely, the goal is to provide certainty of the status of a product in the mind of consumers who enjoy it. Therefore halal certificates are very influential to consumers.

The Indonesian Council of Religious Scholars halal certificate holders are responsible for maintaining the page of the products they produce, and these certificates are non-transferable. The validity period of the halal certification is two years, which can then be renewed. The provision is intended to maintain the manufacturer's consistency during the validity of the certificate. Certificates that expire, including photocopies, may not be used or installed for specific purposes.

- Benefits of Halal Certificate

- Provides the inner peace of consumers Products that already have halal guarantees directly provide inner peace for their consumers because there is no doubt whether the raw materials and the production process of these goods are not done correctly.

- $\quad$ Products Will Have Unique Selling Point (USP) as one way to compete with competitors, of course, having a halal certificate can be a USP power because it has advantages that other competitors do not have.

- Improving Ability in Marketing in Muslim Markets/ Countries

- Increasing Consumer Confidence in Indonesia, the majority of consumers are Muslim. One of the essential needs of Muslims is the consumption of halal products. The manufacturer's good faith is to provide products following Muslim consumer consumption standards, namely idolatry. There is nothing more valuable to a seller than giving protection to his customers, with which customer loyalty can also be built.

- The purpose of Halal Certification of Halal MUI Certification in food products, drugs, cosmetics, and other products is to provide certainty of idolatry status to reassure consumers in consuming it. The manufacturer guarantees the continuity of the halal production process by implementing the Halal Assurance System.9 With the halal certification in the culinary business, of course, makes the community feel calm about the procedures, raw materials, and processing of the food itself so that the community does not hesitate and decide to buy the food.

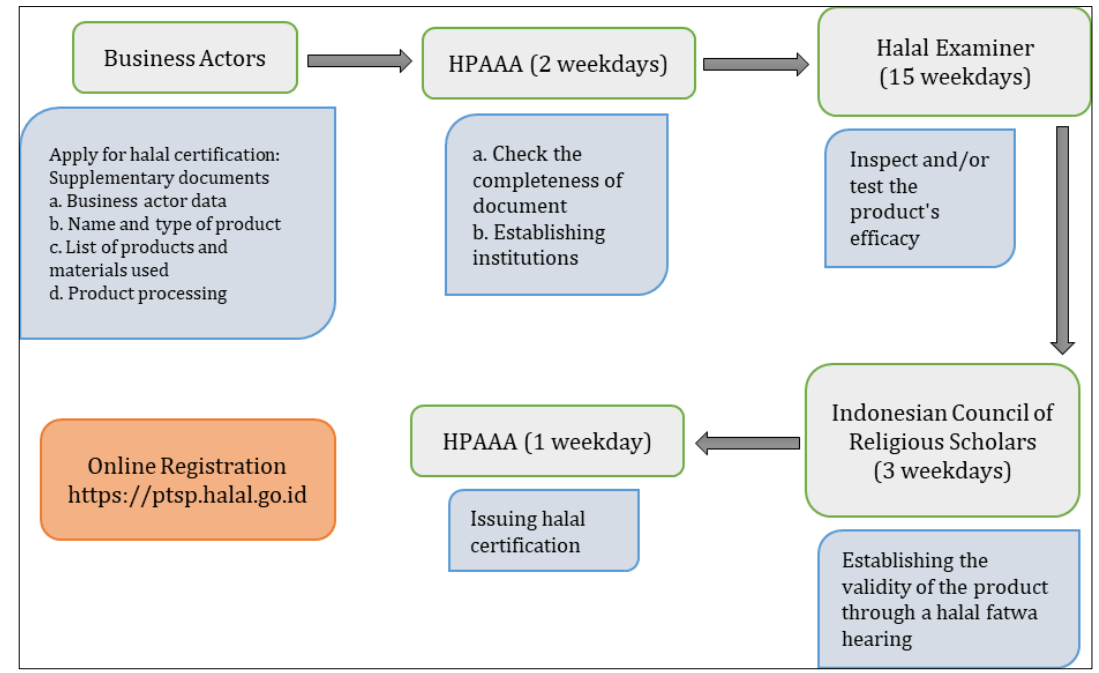

Figure 1 The Halal Certification Process Flow

\section{Research Method}

This research is qualitative, sharpened through data analysis, namely by categorizing various data and arguments to explain the policy model of halal product assurance certification. The data obtained will also be mapped based on the order of time, events, determination of the subject, and place. The point is to describe well the chronological that occurs in the political economy of halal certification. The next step that needs to be done is to understand the background of the emergence of halal certification policy to digest its various problems and further understand the existence or absence of political motives and specific interests. The final step is to construct the existing policy model precisely by decrypting it appropriately.

Data collection is done through documents from agencies, articles, expert opinions or stakeholders interested in halal certification, and comments commented on interest groups. The agencies and documentation in question are MUI, the 
Halal Product Guarantee Bill proposed by the Ministry of Religious Affairs, and other agencies that are still related. In comparison, the articles used as references and additions to discourse are none other than articles published in the mass media, whether in daily newspapers, magazines, journals, books, or on internet sites. While stakeholders or parties are interested in halal certification, of course, MUI itself and actors who are closely positioned in the related implementation of halal certification, such as religious groups (members of faith-based organizations).

In other words, data collection is also taken through interview techniques. Interviews, in this study, are devices for producing situated understandings derived from special interactional episodes. This method is strongly influenced by the personal characteristics of researchers, including race, social class, tribal, and gender (Denzin and Lincoln, 2009). Despite it all, it is expected that the interpretation of the interview results can still produce objective results that many audiences can accept. Interview results are used to complement the view of the conflict that occurred. Considering that some interviews cannot be done directly (face to face) due to bureaucratic requirements constraints and the length of time it takes to meet the requirements, some interviews are conducted by e-mail.

In the end, interviews via e-mail do not produce satisfactory answers from sources due to reluctance or unable to. However, with the limited available data, the data collected is then processed and sorted according to research needs. The next step is to analyze and present it in a description.

\section{Results and Discussion}

The Ministry of Religious Affairs has the task of organizing halal product guarantees following Law No. 33 of 2014 on Halal Product Guarantee and Government Regulation No. 31 of 2019 on The Implementation of Law No. 33 of 2014 halal product guarantee. Referring to the Law and the PP, HPAAA carries out the implementation of halal product guarantees. HPAAA is authorized to issue halal certificates on products that enter, circulate, and are traded in the territory of Indonesia.

HPAAA cooperates with relevant ministries and institutions, the Indonesian Council of Religious Scholars, and Halal Examiner so that the goal of implementing halal product guarantees is to provide comfort, security, safety, and certainty of the availability of halal products for the public in consuming and using products, and increasing added value for businesses to produce and sell halal products.

To support the ease of access of business actors in obtaining halal certification services, HPAAA develops the governance of halal certification services for business actors, especially micro and small businesses. In this regard, HPAAA streamlines facilities and infrastructure in the Regional Office - 5 - Ministry of Religious Affairs so that halal certification services are carried out in the area effectively and efficiently. Effective and efficient implementation of halal certification services needs to be followed by changes in work culture so that halal certification service standards are required.

The goal to be achieved with this Implementation Procedure is so that the services carried out by HPAAA and the Regional Task Force are following procedures, procedures, compliance with regulations, and service management to provide the best service to the community.

The time of application for certification is as follows:

- Application for the halal certificate at HPAAA or Regional Task Force: 1 (one) business day.

- After the mechanisms and procedures of halal certification services are met, the issuance of halal certificates is at most 3 (three) working days.

Fees or rates in halal certification damage

- Before the Regulation of the Minister of Finance on halal certification service rates is issued, then:

- the application for a halal certificate in HPAAA and Regional Task Force is free of charge;

- the cost of inspection and testing of halal products following the provisions applicable to the regulationrecognized Halal Examiner.

- If the regulation of the Minister of Finance on halal certification on tariffs is issued, the amount of halal certification service fees will be adjusted to the provisions of the Head of HPAAA.

Furthermore, in the process of service, products are as follows:

1. Administrative services provided to businesses to obtain halal certificates, including: 
a. New Application for a halal certificate for products that have not received a halal certificate issued by HPAAA.

b. Application for renewal of halal certificate renewal application no later than 3 (three) months before the validity period of the halal certificate expires.

c. Changes in the Composition of Application Materials for products whose halal certificates are issued by HPAAA are still valid and change the composition of materials.

2. Public service Consulting Services provided to the public to obtain information, explanations, mechanisms, and procedures of the halal certification process.

In implementing halal certification, HPAAA, through its officers, must have the competence of implementation. Halal certification service officers must have the following competencies:

- $\quad$ able to understand the regulation of halal product guarantees;

- know halal certification service products;

- $\quad$ able to verify and validate documents;

- $\quad$ able to communicate orally and in writing well;

- able to coordinate and cooperate in the team;

- able to operate the computer properly;

- able to manage documents;

- have a well-mannered attitude of serving and good performance.

In addition to implementation competence, HPAAA also conducts internal Supervision by auditors who have been appointed to carry out halal product inspections, while internal Supervision is:

1. Internal Supervision of service personnel as the fulfillment of service standard components, carried out in tiers, namely:

a. Echelon IV officials or appointed officials carry out Supervision of the executor.

b. Echelon III officials or appointed officials supervise echelon IV officials.

c. Echelon II officials control Supervision of echelon III officials.

d. Supervision of echelon II officials is carried out by echelon I officials.

2. All halal certification services are supervised by the Inspectorate General of the Ministry of Religious Affairs.

Following handling complaints, suggestions, and inputs. Business actors can submit complaints about service dissatisfaction, advice, and feedback provided by Halal Certification service officers. Complaints, suggestions, and feedback can be submitted by email sent to humasbpjph@kemenag.go.id email address.

Furthermore, the service implementer by HPAAA is as follows:

1. Halal certification service officers/implementers consist of at least:

a. Front Office Officer who provides direct services to the community and business actors in consulting services and halal certification registration services.

b. Back Office Officers who support the implementation of front office officer services include:

- Preparation of halal certification service materials.

- E-mail in verification and validation of digital documents of business actors and submission of digital papers to HPAAA and Halal Examiner.

- Digitization and administrating of documents.

- Document management.

- $\quad$ Other matters related to halal certification service products.

2. Number of service implementers serving:

a. HPAAA, at least 8 (eight) people include 5 (five) front office officers and 3 (three) back-office officers.

b. Regional Task Force, at least 3 (three) people, including 2 (two) front office officers and 1 (one) back-office officers.

3. The officer, as referred to in point 1 , is determined by the Head of HPAAA or the Head of the Ministry of Religious Affairs

\section{Conclusion}

Based on the results of the research that has been submitted, it can be concluded as follows:

- Halal certification seen from economic factors will increase the benefits of business actors. Because people from various walks of life, if they want to buy food, drinks, and the like, must see the halal certification logo to ensure that the food and beverage consumed get guaranteed idolatry. 
- In terms of economy, goods or services offered by producers to the community will be profitable if business actors have halal certification compared to business actors who do not have halal certification and have an impact on the sale of halal products so that with this impact, business actors who do not have halal certificates will take care of their halal certificates to the local HPAAA.

- $\quad$ HPAAA, as a body that has an automatic in issuing halal certification, must conduct an assessment, process, product supervision, and product manufacturing flow of business actors before issuing halal certification with a fatwa from MUI.

- HPAAA, having authority in the issuance of halal certification, must cooperate with e-Halal Decree, Halal Examiner, and related institutions to process halal certification.

Judging from the work of HPAAA on the issuance of halal certification, which is viewed from the economic side, it is necessary to simplify the processing of halal certificates to the community or business actors so that the alignment will reduce economic costs for business actors and provide convenience to businesses in the management of halal certification in the future.

\section{Compliance with ethical standards}

\section{Acknowledgments}

We want to thank all partners for this literature study of Halal Centre in Universitas Pembangunan Panca Budi Medan. We still need the suggestion of others about this research development.

\section{Disclosure of conflict of interest}

There is no conflict of interest.

\section{References}

[1] Bohari, Abdul Manaf, Hin Cheng Wei, dan Fuad Nurwahida. "The competitiveness of halal food industry in Malaysia: A SWOT - ICT analysis." Malaysia Journal of Society and Space. 2013; 9(1): 4.

[2] Burhanuddin, pemikiran hukum perlindungan konsumen dan sertifikasi halal (Malang: UIN-Maliki press) hlm. 2011; 142.

[3] Kusumaningrum, Demeiati Nur, dkk., Trend Pariwisata Halal Korea Selatan, SENASPRO 2017 UMM, hal. 856.

[4] Faridah Hj. Hassan, Halal Food Marketing: Dare To Win! (Universiti Teknologi Mara: Penerbit Press, 2013), hal. 26

[5] https://sialcanada.com/oldsial/wp-content/uploads/2017/05/Halal-Insights-Workshop-for-public.pdf. Diakses pada (14/09/2018 16.32 WIB)

[6] http://repository.uin-suska.ac.id. Diakses pada 20 april 2019.

[7] Isa Ma, "Halal Markets in China: Potential and Prospects", Universiti of Malaya, diakses dalam.

[8] Lufi Wahidati dan Eska Nia Sarinastiti, "Perkembangan Wisata Halal di Jepang”, Jurnal Gama

[9] May Lim Charity, 2017, Jaminan Produk Halal di Indonesia, Direktorat Jenderal Peraturan Perundang-undangan Kementrian Hukum dan HAM, Jurnal Legislasi Indonesia. 01 Maret 2017; 14: hlm. 101

[10] Miriam Budiardjo, Masalah Accountability dalam Ilmu Politik. Pidato Pengukuhan Gelar Doktor Kehormatan dalam Ilmu Politik. Universitas Indonesia. 13 Desember 1997.

[11] Muslim China Bangun Industri Halal, Kompas, diakses dalam.

[12] Ramlan, sertifikasi sebagai penerapan etika bisnis islami dalam upaya perlindungan konsumen muslim. 01 januari 2014; 14: 152.

[13] Jivrac, Salima and McArthur, Jo-Ann. "The Canadian Halal Market: Insight and Opportunities". Diakses pada 20 Januari 2021.

[14] Samori, Zakiah, et al. Review current trends on halal tourism: cases on selected asian countries. Tourism Management Perspectives, 19 (B), 131²136. Societa. 1 Januari 2018; 1: hal. 10. 